\title{
TANGGUNG JAWAB NEGARA DALAM MASA PANDEMI COVID-19
}

\author{
Fradhana Putra Disantara* \\ Fakultas Ilmu Sosial dan Hukum, Universitas Negeri Surabaya, \\ Jl. Ketintang, Ketintang, Kec. Gayungan, Kota SBY, Jawa Timur 60231 \\ e-mail: dfradhana@gmail.com
}

\begin{abstract}
The Coronavirus Disease 2019 (COVID-19) pandemic encourages the government to take various strategic steps to accelerate the handling of COVID-19. One of the strategic policies undertaken by the government is the implementation of Large-Scale Social Restrictions in various cities or districts in Indonesia. However, this abnormal policy does not mean abandoning government responsibility for all lines of community life. This legal research is aimed at analyzing the state's responsibilities in the COVID-19 pandemic and also providing formulations related to future law (ius constituendum) on the state of emergency national law. This legal research uses the statute approach and conceptual approach. Primary and secondary legal materials used in this legal research are inventoried in order to obtain proper studies and provide critical study of the legal issues discussed. The results of the study stated that state responsibility during the COVID-19 pandemic had been legitimized by existing national and international legal provisions. The LargeScale Social Restrictions Policy (PSBB) should not derogate the principle rights of the community. For this reason, the responsibility of the state must be optimized because the community has a central position in a country. Then, a new formulation is needed as an umbrella act in the regulation of national emergency status. This is because existing laws are not relevant to current conditions.
\end{abstract}

Keywords: Responsibilities; COVID-19; Umbrella ACT; PSBB.

\begin{abstract}
Abstrak
Pandemi Coronavirus Disease 2019 (COVID-19) mendorong pemerintah untuk melakukan berbagai langkah strategis sebagai bentuk percepatan penanangan COVID-19. Salah satu kebijakan strategis yang dilakukan oleh pemerintah adalah penerapan Pembatasan Sosial Berskala Besar yang dilakukan di berbagai kota atau kabupaten di Indonesia. Namun, kebijakan abnormal tersebut bukan berarti menanggalkan tanggung jawab pemerintah terhadap segala lini kehidupan masyarakat. Penelitian hukum ini bertujuan untuk menganalisa terkait tanggung jawab negara dalam masa pandemi COVID-19 serta memberikan formulasi terkait pengaturan di masa mendatang (ius constituendum) tentang status darurat hukum nasional. Penelitian hukum ini menggunakan metode statute approach dan conseptual approach.Bahan hukum primer dan sekunder digunakan dalam penelitian hukum ini diinventarisir guna mendapatkan kajian yang semestinya serta memberikan telaah kritis atas isu hukum yang dibahas.Hasil penelitian menyatakan bahwa tanggung jawab negara dalam masa pandemi COVID-19 telah terlegitimasi dengan ketentuan hukum nasional maupun internasional yang ada. Kebijakan Pembatasan Sosial Berskala Besar (PSBB) hendaknya tidak menderogasi hak-hak prinsipil masyarakat. Untuk itu, tanggung jawab negara tersebut harus tetap dioptimalkan mengingat masyarakat memiliki posisi sentral di dalam suatu negara.. Kemudian, diperlukan suatu formulasi baru sebagai umbrella act dalam pengaturan status darurat nasional. Hal ini dikarenakan undang-undang yang telah ada tidak relevan dengan kondisi saat ini.
\end{abstract}

Kata Kunci : Tanggung Jawab, COVID-19, Umbrella Act, PSBB,

*Naskah diterima: 03 Juni 2020, direvisi: 18 September 2020, disetujui untuk terbit: 28 September 2020

Doi: $10.3376 /$ jch.v6i1.262 


\section{PENDAHULUAN}

Pandemi Coronavirus Disease 2019 (COVID-19) nyatanya memberikan dorongan bagi suatu negara untuk mengambil kebijakan yang 'abnormal' demi memutus mata rantai COVID-19 (Bergkamp, 2020: 345), tak terkecuali di Indonesia. Dalam menghadapi pandemi tersebut, akhirnya pemerintah menerbitkan satu paket aturan sebagai legitimasi formil penanganan COVID-19, yakni Keputusan Presiden No. 11 Tahun 2020 tentang Penetapan Kedaruratan Kesehatan Masyarakat (selanjutnya disebut dengan KEPPRES Kedaruratan Kesehatan), Peraturan Pemerintah No. 21 Tahun 2020 tentang Pembatasan Sosial Berskala Besar Dalam Rangka Percepatan Penanganan Covid 19 (selanjutnya disebut dengan PP PSBB) yang sebenarnya menjadi tindak lanjut dari Pasal rumusan 15 Ayat (2) dan Pasal 56 Undang Undang Nomor 6 tahun 2018 tentang Kekarantinaan Kesehatan (selanjutnya disebut dengan UU Kekarantinaan Kesehatan), dan Peraturan Pemerintah Pengganti undang-undang No. 1 Tahun 2020 tentang Kebijakan Keuangan Negara Dan Stabilitas Sistem Keuangan Negara Untuk Penanganan Pandemi Covid 19 Dan/Atau Dalam Rangka Menghadapi Ancaman Yang Membahayakan Perekonomian Nasional Dan/Atau Stabilitas Sistem Keuangan (Selanjutnya disebut dengan PERPPU No. 1 Tahun 2020). Tentu, terbitnya ketiga peraturan tersebut memberikan implikasi, salah satunya PP PSBB yang memberikan legitimasi atas opsi yang dipilih oleh pemerintah untuk memutus penyebaran
COVID-19, yaitu opsi Pembatasan Sosial Berskala Besar (Disantara, 2020d).

Opsi PSBB tentu menimbulkan konsekuensi kepada pemerintah, yaitu tanggung jawab pemerintah atau negara kepada masyarakat dalam masa pandemi COVID-19. Tanggung jawab negara terhadap masyarakat dalam pandemi COVID-19 sudah sangat menjadi penting, mengingat bahwa rakyat merupakan 'pemilik' atas kedaulatan tertinggi di Indonesia (Pasal 1 Ayat (2) UndangUndang Dasar Negara Republik Indonesia tahun 1945). Maknanya, segala aspek kekuasan pemerintah berasal dari rakyat. Hal ini menunjukkan bahwa rakyat memiliki posisi yang prinsipil dan sentral dalam keberlangsungan jalannya pemerintahan suatu negara. Negara merupakan 'alat' dari masyarakat untuk mencapai harapan bangsa.

Konstruksi berpikir demikian sehendaknya juga berlaku dalam kebijakan PSBB. Tanggung jawab moral dan hukum kepada masyarakat masih berada dalam pundak pemerintah. Meski pada saat pandemi COVID-19, negara wajib setia menjalankan aktivitas berbangsa dan bernegara dengan pertimbangan nurani dan nilai-nilai moral yang tumbuh dan berkembang di masyarkat guna mewujudkan cita-cita hukum yaitu Pancasila.

Namun, tindakan penetapan status darurat kesehatan menimbulkan problematik, yakni apakah kedaruratan COVID-19 di Indonesia sama dengan 'keadaan bahaya' atau 'kegentingan yang memaksa' (Disantara, 2020a). Hal itu 
ditunjukkan dengan penetapan status 'keadaan bahaya' atas pandemi COVID-19 dengan KEPPRES Kedaruratan Kesehatan oleh pemerintah, namun di sisi lain pemerintah menetapkan bahwa pandemi COVID-19 merupakan 'kegentingan yang memaksa' dengan diterbitkannya PERPPU No. 1 Tahun 2020.

Penetapan status hukum darurat di Indonesia wajib berdasarkan Pasal 12 Undang-Undang Dasar Negara Republik Indonesia tahun 1945 (selanjutnya disebut dengan UUD NRI 1945) yang menyatakan Presiden menyatakan keadaan bahaya; Syarat-syarat dan akibatnya keadaan bahaya ditetapkan dengan undang-undang, dan rumusan Pasal 22 Ayat (1) UUD NRI 1945 yang menyatakan dalam hal ihwal kegentingan yang memaksa, Presiden berhak menetapkan peraturan pemerintah sebagai pengganti undang-undang.

Dalam hal 'keadaan bahaya', penetapan status darurat juga didasarkan pada Peraturan Pemerintah Pengganti Undang-Undang No.23 Tahun 1959 tentang Pencabutan Undang-Undang Nomor 74 Tahun 1957 (Lembaran Negara No. 160 Tahun 1957) dan Penetapan Keadaan Bahaya. Namun, penetapan 'keadaan bahaya' dengan menggunakan aturan tersebut dianggap tidak relevan dengan keadaan sekarang.

Oleh karena itu, diperlukan peraturan perundang-undangan yang menjadi peraturan payung (umbrella act) terkait penetapan status darurat hukum, baik dalam hal 'kegentingan yang memaksa' maupun ' keadaan bahaya'. Hadirnya umbrella act tersebut diharapkan mampu memberikan kepastian hukum dan pertanggungjawaban negara terhadap masyarakat dalam masa darurat di masa yang akan datang.

Penelitian ini bertujuan untuk menganalisa terkait tanggung jawab negara dalam masa pandemi COVID-19 serta memberikan formulasi terkait pengaturan di masa mendatang (ius constituendum) tentang status darurat hukum nasional. Maka dari itu, dari beberapa uraian di atas, penelitian ini terdiri atas dua rumusan masalah. Pertama, terkait 'bagaimana' tanggung jawab negara terhadap masyarakat dalam masa pandemi COVID-19. Kedua, bagaimana pertanggungjawaban negara dalam ius constituendum keadaan darurat.

\section{METODE PENELITIAN}

Jenis dari penelitian ini adalah penelitian hukum. Penelitian hukum (legal research) adalah menemukan kebenaran koherensi, yaitu adakah aturan hukum sesuai norma hukum dan adakah norma yang berupa perintah atau larangan itu sesuai dengan prinsip hukum, serta apakah tindakan (act) seseorang sesuai dengan norma hukum (bukan hanya sesuai aturan hukum) atau prinsip hukum (P. M. Marzuki, 2017).

Penelitian hukum ini menggunakan metode pendekatan pendekatan konseptual (conceptual approach) dan (statue approach) peraturan perundang-undangan (Disantara \& Prasetio, 2020b: 44). Penelitian hukum ini menggunakan bahan hukum primer sekunder (I. Marzuki \& Faridy, 2020), dalam bentuk peraturan perundang-undangan yang berkaitan 
dengan isu hukum yang dibahas serta publikasi hukum termasuk buku-buku teks, kamus hukum, jurnal hukum, dan literatur hukum lainnya (Said, 2018).

\section{HASIL DAN PEMBAHASAN}

\section{Tanggung Jawab Negara dalam Masa Pandemi COVID-19}

Masa pandemi COVID-19 tentu memberikan pemerintah tanggung jawab atas ketertiban, keamanan, kenyamanan, dan kesejahteraan masyarakat. Tanggung jawab negara dapat kita lihat dalam alinea ke-IV Pembukaan Undang-Undang Dasar Negara Republik Indonesia tahun 1945 yaitu melindungi segenap bangsa Indonesia dan seluruh tumpah darah Indonesia, memajukan kesejahteraan umum, mencerdaskan kehidupan bangsa, dan ikut melaksanakan ketertiban dunia yang berdasarkan kemerdekaan, perdamaian abadi dan keadilan sosial.

Empat tanggung jawab diatas merupakan amanah oleh para pendiri bangsa bagi para penyelenggaraan negara. Kemudian, telah kita ketahui bersama, bahwa Indonesia merupakan negara yang berdiri berdasarkan atas hukum (rechtsstaat) bukan berdasarkan kekuasaan semata (Disantara, 2020a: 66). UUD NRI 1945 memiliki posisi yang prinsipil sebagai pedoman atas tata dan laksana kehidupan kenegaraan, pemerintahan, dan kemasyarakatan, tak terkecuali menegaskan eksistensi konsep negara.

Hal tersebut telah ditegaskan pada Pasal 1 ayat 3 UUD NRI 1945 yang berbunyi bahwa "Negara Indonesia adalah negara hukum". Implikasinya, segala tindakan penyelenggaraan negara (termasuk PSBB) harus didasarkan atas instrumen hukum yang bermuara pada tujuan negara, yakni melindungi dan mensejahterakan.

Kebijakan PSBB harus mencerminkan suatu keadilan sosial dalam segala aspek serta melindungi segenap seluruh unsur bangsa. Meski PSBB menciptakan ekses yang besar dalam segala lini kehidupan, negara tetap wajib memenuhi segala kebutuhan primer guna mencerminkan penyelenggaraan, pelayanan, pemberdayaan, dan pembangunan publik yang prima (Disantara, 2020b).

Di sisi lain, tentu kebijakan tersebut dapat membatasi pergerakan manusia. Harus dimengerti bahwa hadirnya PP PSBB tak lepas dari hadirnya KEPPRES Kedaruratan Kesehatan dan UU Kekarantinan Kesehatan. PSBB merupakan salah satu tindak lanjut dari status kedaruratan kesehatan masyarakat.

Merujuk dalam Pasal 1 PP PSBB, PSBB adalah pembatasan kegiatan tertentu penduduk dalam suatu wilayah yang diduga terinfeksi Corona Virus Disease 2019 (COVID-19) sedemikian rupa untuk mencegah kemungkinan penyebaran Corona Virus Disease 2019 (COVID-I9). Pertimbangan pelaksnaan PSBB meliputi enam unsur, yakni epidemologis, besarnya ancaman, efektifitas, dukungan sumber daya, teknis operasional, dan pertimbangan ekonomi, sosial, budaya dan keamanan.

Hal ini bermakna bahwa penerapan PSBB disuatu daerah diperlukan pertimbangan yang holistik dengan 
melihat konsekuensi dan resiko dari penerapan kebijakan tersebut. Minimal, refleksi kebijakan PSBB terdiri atas peliburan sekolah dan tempat kerja, kegiatan keagamaan, dan kegiatan di tempat atau fasilitas umum. Namun, pada faktanya kebijakan PSBB dapat dikatakan 'datang terlambat'. Beberapa instansi pendidikan telah melakukan peliburan perkuliahan, sehingga kegiatan belajar mengajar secara online.

Dampak yang ditimbulkan dari kebijakan PSBB tentu harus dapat diatasi oleh negara, dan tentunya menjadi tanggung jawab negara pula. Ditinjau dari Pasal 4 PP PSBB, PSBB yang diterapkan oleh pemerintah pusat maupun pemerintah daerah mengeluarkan suatu tanggung jawab atau konsekuensi, yakni baik pemerintah pusat maupun pemerintah daerah harus memperhatikan pemenuhan kebutuhan dasar penduduk, mulai dari pangan, pelayanan kesehatan, dan kehidupan sehari-hari lainnya.

Pemenuhan kebutuhan primer tersebut disesuaikan dengan kondisi suatu wilayah yang terjangkit COVID-19. Apabila melihat dari rumusan Pasal 4 PP PSBB, maka PP PSBB tidak secara tegas dan jelas mengatur mengenai tanggung jawab negara atas kebijakan PSBB terhadap masyarakat yang telah terkena dampak, khususnya dalam aspek pemenuhan kebutuhan dasar penduduk.

Kemudian, apabila merujuk dalam Pasal 8 UU Karantina Kesehatan, pemerintah pusat dan daerah tetap bertanggung jawab atas kepastian terpenuhinya segala lini kebutuhan hidup masyarakat selama diterapkannya PSBB, khususnya keperluan kebutuhan medis dan kebutuhan pangan. Tanggung jawab pemerintah juga terdapat dalam UU Kekarantinaan Kesehatan. Dalam hal penanganan pandemi COVID-19, Pasal 4 UU Kekarantinaan Kesehatan telah memberikan tanggung jawab baik pemerintah pusat dan Pemerintah Daerah untuk melindungi kesehatan masyarakat dari penyakit dan/atau faktor dari risiko kesehatan setiap orang yang dikhawatirkan dapat menimbulkan kedaruratan kesehatan masyarakat yang dilakukan melalui kekarantinaan kesehatan.

Selanjutnya, Pasal 6 UU Kekarantinaan Kesehatan juga memberikan tanggung jawab terhadap pemerintah pusat dan Pemerintah Daerah atas kesiapan segala sumber daya yang diperlukan dalam masa penyelenggaraan kekarantinaan kesehatan. Oleh karena itu, setiap orang berhak untuk mendapatkan tanggung jawab dari pemerintah selama masa pandemi COVID-19.

Hakikatnya, pertanggung jawaban negara harus tetap setia bersama masyarakat baik dalam kondisi normal maupun tidak normal, seperti halnya pada pandemi COVID-19 ini. Pertanggung jawaban tersebut diutamakan pada lini masyarakat yang terkena dampak dengan adanya pandemi COVID-19 maupun kebijakan pemerintah dalam penanganan COVID-19. Apabila ditinjau dari perspektif pertimbangan PSBB, maka pemerintah pusat dan daerah hendaknya 
terus melakukan sosialisasi secara massif guna meningkatkan aspek kedisiplinan masyarakat dalam mematuhi rambu-rambu peraturan yang ada.

Pemerintah pusat dan daerah harus secepat mungkin untuk mengidentifikasi area dan subjek mana saja yang berpotensi terjangkit COVID-19. Kemudian, diperlukan tindakan yang tegas oleh aparatur negara terhadap pihak yang melanggar ketentuan dari peraturan yang ada. Selanjutnya, diperlukan optimalisasi Gugus Tugas COVID-19 dari tingkat paling rendah $(\mathrm{RT} / \mathrm{RW})$ hingga tingkat paling tinggi.

Alinea IV UUD NRI 1945 menyatakan bahwa tujuan negara yakni melindungi segenap bangsa Indonesia dan seluruh tumpah darah Indonesia. 'Melindungi' dalam tempo ini dapat dikonkritkan sebagai penyelenggaraan pertanggungjawaban negara untuk melindungi masyarakat dari pandemi COVID-19. Pertanggung jawaban ini berlaku bagi seluruh rakyat baik yang berada dalam negeri maupun luar negeri. Tanggung jawab negara juga terdapat dalam Pasal 28 H UUD NRI 1945, bahwa negara berkewajiban terhadap pemenuhan layanan kesehatan (Pasal 28 H Ayat (1) UUD NRI 1945), dan berkewajiban terhadap pemenuhan jaminan sosial kepada masyarakat (Pasal 28 H Ayat (3) UUD NRI 1945).

Negara harus bertanggung jawab atas penyediaan fasilitas pelayanan kesehatan yang layak dalam penanganan COVID-19 (Pasal 34 Ayat (3) UUD NRI 1945) Oleh karena itu, pelaksanaan kebijakan PSBB harus memperhatikan pemenuhan jaminan sosial dan pelayanan kesehatan bagi masyarakat. Selanjutnya, dalam perspektif hak asasi manusia, setiap orang berhak untuk menikmati standar kesehatan fisik dan mental tertinggi yang dapat dicapai dalam masa pandemi COVID-19.

Negara harus mengambil tanggung jawab utama untuk mencegah, mengobati, dan mengendalikan pandemi COVID-19. Aspek tanggung jawab pemerintah juga dapat dilihat dari aspek hukum internasional. Draft Articles om the Responbility of State for Internationally Wrongful Acts dari International Law Commission menyatakan terdapat dua kriteria makna dari frasa "Internationally Wrongful Acts" (Distefano, 2019: 701), yaitu tindakan tersebut harus dikaitkan dengan negara di dasarkan dengan hukum internasional dan merupakan pelanggaran dari kewajiban internasional yang dilakukan oleh suatu negara. Sehingga, apabila ditinjau dalam hukum internasional, tindakan yang salah yang telah dilakukan pemerintah harus disertai dengan tanggung jawab.

Tindakan salah tersebut dapat berupa tindakan yang disengaja maupun kelalaian. Paramater dari "Internationally Wrongful Acts" adalah tidak ada kondisi mental yang khusus yang diperlukan sehubungan dengan pelanggaran kewajiban utama negara, hanya tindakan negara yang terpenting yang diukur oleh Komisi Hukum Internasional terlepas dari niat apapun (Suthar et al., 2018).

Tanggung jawab negara dapat dikatakan benar apabila injury yang 
disebabkan dan dianggap berasal dari suatu tindakan yang salah dari suatu negara secara internasional (Broberg, 2020). Dalam menentukan 'benar' atau 'salah' dari suatu tindakan negara, harus diidentifikasi atas serangkaian kelalaian maupun tindakan salah yang dilakukan oleh suatu negara apakah telah menjadi faktor substansial yang menimbulkan kerugian dalam masa pandemi COVID-19 atau tidak.

Sehingga, dalam masa pandemi COVID-19, suatu tindakan dari pemerintah tersebut dapat dikatakan "Internationally Wrongful Acts" manakala tindakan pemerintah justru mengakibatkan memperburuk pandemi COVID-19.

Kerangka hukum internasional memberikan kewajiban bagi negara-negara yang melanggar hukum internasional untuk melakukan reparasi penuh atas kerugian yang disebabkan oleh tindakan yang salah secara internasional. Pemerintah harus secara melakukan suatu tindakan hukum sesuai dengan aturan hukum internasional yang paling spesifik dalam mengatur penyakit menular dan kesehatan umum, yaitu International Health Regulations 2005.

Penghormatan suatu negara terhadap International Health Regulations 2005 hakikatnya bertujuan untuk mencegah, melindungi, mengendalikan dan memberikan respons kesehatan masyarakat terhadap penyebaran pandemi COVID-19 (Gostin \& Meier, 2019: 790). Apabila ditinjau dari Pasal 16 International Covenant on Economic, Social and Cultural Rights (ICESCR) 1966 sebagaimana yang telah diratifikasi oleh Indonesia dengan Undang-undang Nomor 11 tahun 2005 tentang Pengesahan Kovenan Internasional Tentang Hak-Hak Ekonomi, Sosial, dan Budaya, pemerintah Indonesia memiliki tanggung jawab untuk melakukan segala sesuatu yang diperlukan guna mengupayakan pencegahan, pengobatan, dan pengendalian dari pandemi COVID-19.

Dalam hal PSBB, negara harus tetap menjamin hak-hak masyarakat yang berkaitan dengan aspek ekonomi dan sosial. Sehingga, meski dalam situasi penanggulangan COVID-19, negara dapat memberikan keberlangsungan hidup bagi masyarakat. Tanggung jawab negara kepada masyarakat dalam masa pandemi COVID-19 juga dapat dilihat dari aspek Undang-Undang Nomor 24 Tahun 2007 tentang Penanggulangan Bencana (selanjutnya disebut dengan UUPB). Hal ini dikarenakan COVID-19 telah ditetapkan sebagai bencana non alam nasional melalui Keputusan Presiden Nomor 12 tahun 2020 tentang Penetapan Bencana Non Alam Penyebaran Corona Virus Disease 2019 (COVID-19) Sebagai Bencana Nasional.

Sebagai bencana non alam, tanggung jawab negara terhadap pandemi COVID19 terdapat dalam Pasal 6 UUPB, yaitu bertanggung jawab atas perlindungan masyarakat dari dampak bencana, bertanggung jawab atas penjaminan pemenuhan hak masyarakat dan pengungsi yang terkena bencana secara adil dan sesuai dengan standar pelayanan minimum, bertanggung jawab 
pemulihan kondisi dari dampak bencana. Pemerintah daerah juga memiliki tanggung jawab dalam penanganan COVID-19.

Berdasarkan Pasal 8 UUPB, dalam masa pandemi COVID-19 pemerintah harus memberikan jaminan atas pemenuhan dari setiap orang dan pengungsi yang telah terkena dampak dari adanya pandemi COVID-19 sesuai dengan standar pelayanan minimum. Selanjutnya, pemerintah daerah juga memberikan perlindungan masyarakat atas dampak yang ditimbulkan dari COVID-19. Pemerintah juga bertanggung jawab atas pengurangan risiko COVID-19 dan pemaduan pengurangan risiko COVID-19 dengan program pembangunan. Lalu, dalam aspek ekonomi, pemerintah bertanggung jawab pula atas pengalokasian penanganan dan penanggulangan COVID-19 dalam APBD yang tersedia.

Seharusnya, Pemerintah memberlakukan karantina wilayah sebagai tindak lanjut dari status kedaruratan kesehatan masyarakat. Padahal, Pasal 56 UU Kekerantinaan Kesehatan memberikan tanggung jawab kepada pemerintah atas kebutuhan hidup orang dan makanan hewan ternak selama dalam tempo karantina wilayah. Tentu, hal ini berbeda dengan Pasal 4 PP PSBB.

Dengan tidak memberikan kewajiban memberikan tanggung jawab bagi pemerintah, maka kebijakan pemerintah saat ini menujukkan bahwa pemerintah 'setengah hati' dalam menjamin kebutuhan dasar hidup penduduk. Pemerintah hanya mengedepankan aspek itikad baik semata, tanpa berkewajiban memenuhi kebutuhan primer masyarakat. Sebenarnya, karantina wilayah dapat dilakukan oleh pemerintah apabila pemerintah cermat dalam mengelola aspek perencanaan keuangan. Pemerintah pusat maupun pemerintah daerah dapat melakukan refocussing maupun realokasi anggaran.

Hal tersebut dilakukan guna memotong wacana belanja berbagai lembaga di tingkat pusat maupun daerah yang bukan prioritas dalam masa pandemi COVID-19, sehingga dapat dialokasikan pada penanganan COVID-19. Kebijakan PSBB mencerminkan bahwa prioritas utama pemerintah saat ini adalah aspek kesehatan masyarakat. Namun, aspek kehidupan lainnya juga perlu diperhatikan, mengingat aspek kehidupan manusia berkaitan satu sama dengan yang lain.

Untuk itu, pemerintah pusat maupun pemerintah daerah diharapkan dapat 'merangkul' stakeholder terkait yang juga terkena dampak pandemi COVID-19. Hal ini dapat dilakukan pemerintah dengan cara membeli hasil panen para petani, bekerja sama dengan Unit Mikro Kecil Menengah (UMKM) untuk membuat alat pelindung diri secara mandiri, dan lain sebagainya. Refleksi tersebut dapat mencerminkan bahwa negara benar-benar hadir di dalam masyarakat.

Namun, melihat problematika yang terjadi ini, sehendaknya pemerintah menetapkan status darurat kesehatan dengan pilihan opsi lockdown (karantina wilayah). Hal tersebut dikarenakan opsi PSBB seakan-akan memberikan posisi 
'abu-abu' bagi pemerintah, karena pemerintah tidak wajib menanggung segala lini kehidupan masyarakat, khususnya kebutuhan primer masyarakat. Di sisi lain, opsi PSBB juga 'melepaskan' kewajiban pemerintah untuk menanggung seluruh dampak yang terjadi apabila diberlakukan darurat kesehatan dengan pilihan opsi lockdown (karantina wilayah).

\section{Pertanggungjawaban Negara dalam Ius Constituendum Keadaan Darurat}

Penetapan status darurat di suatu negara dapat membuat pemerintah mengesampingkan terlebih dahulu hak dan kewajiban yang berlaku pada kondisi normal (Gostin \& Hodge, 2020: 1331). Dominasi pendekatan hukum darurat dalam masa pandemi COVID-19 menjadi hal yang lumrah (Shankar, 2018). Aspek prosedur dan substansi dalam penyelenggaraan negara pada masa pandemi COVID-19 tentu juga berbeda dengan penyelenggara negara dalam keadaan normal.

Namun, tanggung jawab negara berkaitan dengan perlindungan hak-hak prinsipil dari manusia sehendaknya tetap dilaksanakan (Cornell \& Salminen, 2018). Hal ini wajib diperhatikan mengingat tanggung jawab negara merupakan hak konstitusional dari setiap warga negara yang telah dituangkan dalam UUD NRI 1945.

Lalu, bagaimana cara menegakkan kembali berkaitan dengan tanggung jawab negara pada masa darurat maupun pada masa pandemi di masa mendatang ? Solusinya adalah diperlukan suatu
Umbrella Act terkait penetapan masa darurat. Hal ini dikarenakan keberadaan Undang-Undang/Prp/No. 23 Tahun 1959 tidak relevan dengan kondisi seperti ini (Disantara, 2020c). Apalagi, hadirnya Putusan Mahkamah Konstitusi No. 138/PUU-VII/2009 memberikan warna baru dalam hal hukum tata negara darurat nasional yakni 'kegentingan yang memaksa' telah termasuk dalam kategori darurat hukum (Disantara \& Prasetio, 2020a).

Apabila berkaca pada fenomena pandemi COVID-19, masih terlihat banyak masyarakat (yang merasakan dampak Luar biasa akibat pandemi COVID-19) belum mendapatkan perlindungan. Oleh karena itu, hadirnya Umbrella Act menjadi hal yang sangat penting, mengingat perlu adanya regulasi yang dapat mewakili seluruh aspirasi masyarakat. Di sisi lain, umbrella act merupakan wujud tanggung jawab moral pemerintah untuk memberikan perlindungan hukum kepada masyarakat. Umbrella Act inilah yang akan menjadi legitimasi formil dalam penanganan pandemi atau wabah apabila terjadi kembali di kemudian hari.

Di sisi lain, berbagai peraturan yang diterbitkan dalam masa pandemi COVID19 hanya sebatas berusaha memenuhi aspek konstitusional yang telah tercantum dalam rumusan Pasal 12 dan 22 UUD NRI 1945. Namun, fenomena yang terjadi adalah ketidakharmonisan antara satu peraturan perundang-undangan dengan peraturan perundang-undangan yang lain.

Bukan hanya mempertegas hak dan kewajiban pemerintah dalam masa darurat, 
umbrella act nantinya menjadi pedoman dan orientasi peraturan perundangundangan yang berada di bawahnya, tak terkecuali peraturan perundang-undangan yang memiliki muatan yang berkaitan dengan umbrella act. Selanjutnya, keberadaan asas dan prinsip dalam umbrella act akan menjadi 'muara' bagi peraturan perundang-undangan yang berada di bawahnya sebagai pelaksanaan secara empirik.

Kerangka hukum fundamental dalam umbrella act diharapkan dapat meminimalisir ketidak harmonisan antara berbagai peraturan perundang-undangan yang terkait. Di sisi lain, umbrella act merupakan salah satu langkah strategis dalam aspek implementasi peraturan yang disesuaikan dengan keadaan yang terus berkembang.

Umbrella act terkait status darurat hukum ini diharapkan dapat menjawab keraguan masyarakat atas anggapan ketidakpastian hukum di dalam peraturan perundang-undangan yang telah diterbitkan oleh pemerintah dalam masa darurat, seperti halnya saat ini. Ketidakpastian tersebut bukan hanya dari segi terminologi dalam norma peraturan perundang-undangan, namun orientasi atau tujuan dari pembentukan umbrella act harus dijelaskan secara expressive verbis.

Penjelasan umum dalam umbrella act harus dijelaskan secara terperinci guna memberikan informasi tambahan. Di sisi lain, jelaskan holistik akan meminimalisir terjadinya miss-interpretasi oleh para pembaca maupun penyelenggara negara.
Oleh karena itu, struktur dan kualitas norma dalam umbrella act harus secara komprehensif mengakomodasi berkaitan dengan segala hal darurat hukum.

Apabila dikaitkan dengan tanggung jawab negara, umbrella act dapat memberikan standar yang sistematis atas bentuk pertanggungjawaban negara dalam masa darurat hukum. Pertanggungjawaban tersebut harus dimaknai secara esensial (Reynolds, 2017: 98), sehingga norma tanggung jawab pemerintah sebagai penyelenggara negara bukan hanya sebatas hitam diatas putih semata.

Pertanggungjawaban merupakan salah satu bentuk kristalisasi dari perlindungan hak asasi manusia dalam masa pandemi COVID-19. Hal tersebut merupakan prinsip dasar atas tuntutan negara untuk menghormati, melindungi, dan memenuhi hak asasi setiap orang. Dalam masa pandemi COVID-19, negara harus hadir dengan memberikan pelayanan yang prima atas aspek kesehatan terhadap masyarakat. Bahkan, negara harus mempersiapkan langkah-langkah strategis untuk mengatasi potensi timbulnya krisis di segala lini. Perlindungan atas keamanan dari masyarakat juga merupakan salah satu cermin dari pertanggungjawaban negara. Hal ini patut diperhatikan mengingat sangat terbuka munculnya konflik horizontal maupun vertikal di antara masyarakat.

\section{SIMPULAN}

Penyelenggaraan praktik kenegaraan harus diwujudkan guna mencapai tujuan hukum dan tujuan bernegara, sekalipun dalam masa Pandemi COVID-19. Oleh 
karena itu, pemerintah harus tetap setia untuk hadir dalam kondisi apapun agar dapat memastikan terpenuhinya hak-hak masyarakat sebagaimana yang telah ditetapkan oleh berbagai peraturan perundang-undangan baik nasional maupun internasional.

Implikasinya, pemerintah tidak dapat mengambil suatu kebijakan dengan tidak memperhatikan tanggung jawab terhadap masyarakat atas pemenuhan hak-hak dasar selama masa Pandemi COVID-19. Tanggung jawab secara moral maupun hukum kepada masyarakat harus tetap dilakukan oleh pemerintah agar membentuk suatu penyelenggaraan pelayanan, pemberdayaan, dan pembangunan publik yang prima dalam masa pandemi COVID-19.

Diperlukan suatu formulasi baru terkait pengaturan penetapan status darurat hukum di masa yang akan datang, yakni dengan solusi umbrella act. Hal ini patut dilakukan melihat orientasi hukum penetapan status darurat hukum yang didasarkan pada Undang-Undang/Prp/No. 23 Tahun 1959 tidak relevan lagi dengan kondisi saat ini.

Di sisi lain, hadirnya umbrella act terkait penetapan status darurat hukum diharapkan dapat mempertegas hak dan kewajiban pemerintah dalam masa darurat, khususnya dalam hal pertanggungjawaban negara sebagai salah satu bentuk refleksi dari perlindungan hak asasi setiap manusia pada masa darurat hukum

\section{UCAPAN TERIMAKASIH}

Penulis mengucapkan puji syukur kepada Allah SWT yang telah memberikan limpahan rahmat, barokah, dan ridha-Nya atas terselesaikan dan terbitnya penelitian hukum yang berjudul Tanggung Jawab Negara dalam masa Pandemi COVID-19. Penulis juga mengucapkan banyak terimakasih kepada seluruh pihak yang membantu secara materiil maupun nonmateriil dalam penyelesaian penelitian ini; khususnya dihaturkan banyak terimakasih kepada Ayah, Ibu, dan adik penulis, Bapak Agus Sugianto dan Ibu Emy Yuliana, serta ananda Geraldha Islami Putra Disantara. Tak lupa, penulis ucapkan terima kasih kepada para Dosen pembimbing dalam tulisan ini, yaitu Bapak Dr. Hananto Widodo, S.H., M.H., Bapak Muh. Ali Masnun, S.H., M.H., Bapak Irfa Ronaboyd, S,H., M.H.; terima kasih pula kepada Bapak/Ibu Dosen Jurusan Hukum Universitas Negeri Surabaya, Tim Peneliti Pusat Kajian Hukum dan Pembangunan Universitas Negeri Surabaya, 'bunga hati' Berlian Lusia Ervianti dan saudara Dicky Eko Prasetio yang telah membantu penulis dalam menyelesaikan penelitian ini.

\section{DAFTAR PUSTAKA}

\section{Buku}

Marzuki, P. M. (2017). Penelitian Hukum: Edisi Revisi (13th ed.). KENCANA.

Reynolds, J. (2017). Empire, Emergency and International Law. Cambridge University Press.

Disantara, F. P. (2020b). Pancasila Juga Volksgeist, Tanya Kenapa? In I. Ronaboyd \& F. P. Disantara (Eds.), Filsafat Hukum Pancasila (Suatu 
Fradhana Putra Disantara: Tanggung Jawab Negara Dalam Masa Pandemi Covid-19

Kajian Filsafat, Hukum, dan Politik)

(pp. 63-68). Kreasi Cendekia Pustaka.

\section{Jurnal}

Bergkamp, L. (2020). State Liability for Failure to Control the COVID-19 Epidemic: International and Dutch Law. European Journal of Risk Regulation, 11(2)

Broberg, M. (2020). A Critical Appraisal of the World Health Organization's International Health Regulations (2005) in Times of Pandemic: It Is Time for Revision. European Journal of Risk Regulation, 11(2), 18.

Cornell, A. J., \& Salminen, J. (2018). Emergency Laws in Comparative Constitutional Law - The Case of Sweden and Finland. German Law Journal, 19(2), 219-250.

Disantara, F. P. (2020a). Aspek Imunitas Dalam Penanganan Corona Virus Disease 2019. Istinbath: Jurnal Hukum, 17(1), 65-82.

Disantara, F. P. (2020c). The Large Scale Social Restrictions Policy For Handling The COVID-19 Pandemic. Jurnal Pembaharuan Hukum, 7(2), 128-141.

Disantara, F. P. (2020d). The Legitimacy of Circular Letter in Handling COVID-19 Pandemic. Rechtsidee, 6(2), 1-10.

Disantara, F. P. (2020e). The Validity of Rectors Circular Letter on the Covid-19 Pandemic. UNIFIKASI: Jurnal Ilmu Hukum, 7(1), 126.

Disantara, F. P., \& Prasetio, D. E. (2020b). The Little Vatican: Optimalisisasi
DWIPA (Desa Wisata Pancasila) sebagai Upaya Meningkatkan Harmonisasi Sosial dan Toleransi. Law, Development \& Justice Review, 3(1), 42-56.

Distefano, G. (2019). State Responsibility for Internationally Wrongful Acts. In Fundamentals of Public International Law (pp. 637-805). Brill | Nijhoff.

Gostin, L. O., \& Hodge, J. G. (2020). US Emergency Legal Responses to Novel Coronavirus. JAMA, 323(12), 1131.

Gostin, L. O., \& Meier, B. M. (2019). Introducing Global Health Law. The Journal of Law, Medicine \& Ethics, 47(4), 788-793.

Marzuki, I., \& Faridy, F. (2020). Relevansi Hukum Dan Hak Asasi Manusia Dengan Agenda Reformasi: Dimensi Nasional Dan Internasional. JCH (Jurnal Cendekia Hukum), 5(2), 350.

Said, M. F. (2018). Perlindungan Hukum Terhadap Anak Dalam Perspektif Hak Asasi Manusia. JCH (Jurnal Cendekia Hukum), 4(1), 141.

Shankar, S. (2018). The State of Emergency in India: Böckenförde's Model in a Sub-National Context. German Law Journal, 19(2), 197218.

Suthar, A. B., Allen, L. G., Cifuentes, S., Dye, C., \& Nagata, J. M. (2018). Lessons Learnt from Implementation of The International Health Regulations: A Systematic Review. Bulletin of the World Health Organization, 96(2), 110-121E. 
Jurnal Cendekia Hukum: Vol. 6, No 1, September 2020

\section{Website}

Disantara, F. P., \& Prasetio, D. E. (2020a). Nalar Hagemonik Perppu COVID $19 . \quad$ Gresnews.Com. http://www.gresnews.com/berita/opi ni/117983-nalar-hagemonik-perppucovid-19/ 